\title{
Penghambatan Ekstrak Daun Kremah (Alternanthera sessilis) Terhadap Enzim a-amilase secara In-Vitro
}

\section{In-vitro Study of $\alpha$-Amylase Inhibition of Kremah Leaves Extract (Alternanthera sessilis)}

\author{
Wirasti Wirasti', Titi Lestari' ${ }^{2}$, Isyti'aroh Isyti'aroh ${ }^{3}$ \\ 1,2 Progam Studi S1 Farmasi, Fakultas Ilmu Kesehatan, Universitas Muhammadiyah Pekajangan Pekalongan \\ (UMPP), Jl. Raya Ambo kembang No 8 Pekalongan Jawa Tengah Indonesia \\ ${ }^{3}$ Program Studi Diploma Keperawatan, Fakultas Ilmu Kesehatan, Universitas Muhammadiyah Pekajangan \\ Pekalongan (UMPP), Jl. Raya Ambo kembang No 8 Pekalongan, Jawa Tengah Indonesia \\ Email: wirasti.kharis@gmail.com
}

Received: 27 Mei 2021; Accepted: 19 Juni 2021; Published: 30 Juni 2021

\begin{abstract}
Abstrak
Pengobatan yang penting untuk Diabetes Melitus (DM) tipe 2 adalah mengendalikan kadar glukosa darah Enzim $\alpha$-amilase di dalam tubuh berperan dalam memecah karbohidrat menjadi amilum. Pengendalian enzim amilase tersebut sangat diperlukan pada kasus diabetes. Tanaman kremah (Alternanthera sessillis) merupakan salah satu tanaman yang bagian daunnya dapat digunakan untuk menurunkan kadar glukosa dalam darah karena mengandung metabolit sekunder salah satunya adalah flavonoid yang dapat menghambat enzim $\alpha$-mylase. Tujuan dari penelitian ini yaitu untuk mengetahui aktivitas dan nilai daya hambat daun kremah terhadap enzim $\alpha$-amilase. Metode yang digunakan dalam penelitian ini yaitu reaksi enzimatis dengan pengukuran intensitas warna menggunakan spektrofotometri UV-Vis. Nilai $\mathrm{IC}_{50}$ yang diperoleh penghambatan enzim $\alpha$-amilase sebesar $101,89 \pm 7,21 \mu \mathrm{g} / \mathrm{mL}$ sedangkan nilai IC $\mathrm{I}_{50}$ acarbose sebesar $127,17 \pm 4,42 \mu \mathrm{g} / \mathrm{mL}$. Hasil ini menunjukkan bahwa ekstrak daun kremah mempunyai aktivitas (hiperglikemia) dengan cara menghambat enzim penghidrolisis karbohidrat kompleks seperti penghambatan enzim $\alpha$-amilase yang baik dibandingkan dengan acarbose karena nilai $\mathrm{IC}_{50}$ ekstrak lebih kecil, sehingga daun kremah mempunyai penghambatan terhadap enzim $\alpha$-amilase.
\end{abstract}

Kata Kunci: Daun Kremah, ekstrak, $\alpha$-amilase, Alternanthera sessillis

\begin{abstract}
An important treatment for type 2 diabetes is controlling blood glucose levels. $\alpha$-amylase enzyme in the body plays a role in breaking down carbohydrates into starch. Control of the amylase enzyme is needed in diabetes cases Kremah plant (Alternanthera sessillis) is a plant whose leaves can be used to lower blood glucose levels because it contains secondary metabolites, one of which is flavonoids which can inhibit the $\alpha$-amylase enzyme. The purpose of this study was to determine the activity and inhibition value of kremah leaves against the $\alpha$-amylase enzyme. The method used in this research is the enzymatic reaction by measuring the intensity of the color using UV-Vis spectrophotometry. The IC50 value obtained by $\alpha$-amylase enzyme inhibition was 101.89 $\pm 7,21 \mu \mathrm{g} / \mathrm{ml}$ while the IC50 acarbose value was $127.17 \pm 4,42 \mu \mathrm{g} / \mathrm{ml}$. These results indicate that kremah leaf extract has activity (hyperglycemia) by inhibiting complex carbohydrate hydrolyzing enzymes such as the $\alpha$-inhibition enzyme $\alpha$-Amylase which is good compared to acarbose because the IC50 value of the extract is smaller, so that the leaves of kremah has inhibiting of the $\alpha$-amylase enzyme.
\end{abstract}

Keywords: Kremah leaf, extract, $\alpha$-amylase, Alternanthera sessillis

\section{PENDAHULUAN}

Diabetes mellitus merupakan suatu keadaan kadar gula darah dalam tubuh melebihi batas normal (hiperglikemia). Salah satu cara untuk mengatasi kadar gula darah yang berlebihan yaitu menghambat enzim penghidrolisis karbohidrat yang disebut enzim $\alpha$-amilase (Rizza, 2010). 
Pemilihan obat-obatan untuk mengatasi diabetes melitus tanpa efek samping, merupakan suatu pertanyaan besar untuk para ahli medis. Pada umumnya obat-obatan sintetis yang digunakan untuk mengatasi diabetes melitus mempunyai efek samping yang buruk, seperti muntah, disentri, migrain, dan anemia. Obat tradisional merupakan pilihan yang baik sebagai alternatif obatobatan sintetis, karena efek samping yang dihasilkan obat tradisional lebih sedikit (Verma et al., 2012). Menurut Informasi yang diperoleh dari Goel (2012), terdapat 800 tanaman yang berpotensi sebagai antidiabetes. Salah satu tanaman obat yang memiliki khasiat tersebut adalah kremah (Alternanthera sessilis). Bagian daun kremah mengandung banyak metabolit sekunder, salah satunya adalah flavonoid yang berpotensi sebagai penghambat enzim penghidrolisis karbohidrat sepetri enzim $\alpha$-amilase.

Penelitian mengenai daun kremah sebagai antidiabetes sebelumnya pernah dilakukan oleh beberapa peneliti. Mrinmay et al (2015) menunjukkan bahwa ekstrak etanol dari daun kremah dengan dosis 200 dan $400 \mathrm{mg} / \mathrm{kgBB}$ mempunyai aktivitas hipoglikemik pada tikus yang diinduksi dengan streptozotocin Dinyatakan pula, bahwa ekstrak etanol tanaman kremah dalam dosis $100 \mathrm{mg} / \mathrm{kgBB}$ memiliki aktivitas antidiabetik karena secara signifikan dapat menurunkan kadar glukosa darah pada tikus yang telah menderita diabetes selama 15 hari.

Penelitian yang telah digunakan oleh peneliti sebelumnya adalah menggunakan metode secara in-vivo. Oleh karena itu, perlu dilakukan penelitian lebih lanjut mengenai mekanisme spesifik ekstrak daun kremah pada penurunana kadar gula darah terutama mengenai penghambatan terhadap enzim $\alpha$ amilase secara in-vitro yang ditunjukkan dengan nilai $\mathrm{IC}_{50}$. Inhibitor consentrasion (IC) 50 adalah konsentrasi penghambat yang dapat menghambat enzim $\alpha$-amilase $50 \%$ (Afriyanti, 2015).

\section{METODE PENELITIAN}

\section{Alat dan Bahan}

Alat-alat yang digunakan dalam penelitian ini adalah alat gelas, vial atau botol kaca, kain saring, vacum rotary evaporator (HEIDOLP), mikropipet, cawan porselen, penangas air, oven, inkubator dan spektrofotometer UVVis (SHIMADZU). Bahan yang digunakan dalam penelitian ini yaitu ekstrak etanol daun kremah (Alternanthera sessilis), etanol 96\%, enzim $\alpha$-amylase, Acarbose, Amilum 5\%, larutan iodine $0,5 \%$, dan larutan dapar phospate.

\section{Determinasi Tanaman}

Determinasi tanaman dilakukan untuk memastikan bahwa tumbuhan yang digunakan untuk penelitian adalah jenis spesies kremah (Alternanthera sessilis).

\section{Pembuatan simplisia daun kremah}

Pembuatan simplisia diawali dengan pengumpulan tanaman kremah yang diperoleh dari Desa Klareyan, Kecamatan Petarukan, Kabupaten Pemalang, Jawa Tengah. Bagian yang digunakan dalam penelitian ini adalah daun kremah yang telah diperoleh dibersihkan dari kotoran yang melekat dengan cara dicuci dengan air mengalir. Setelah itu dikeringkan dengan cara diangin-anginkan pada tempat yang tidak terkena sinar matahari atau dikeringkan dengan oven pada suhu $40^{\circ} \mathrm{C}$. Setelah itu disortasi kembali dan dibuat serbuk dengan menggunakan ayakan nomor 40 Mesh.

\section{Pembuatan ekstrak}

Ditimbang daun kremah yang sudah menjadi serbuk sebanyak 500 gram, kemudian diekstraksi dengan menggunakan metode maserasi, dengan cara merendam simplisia kering daun kremah dalam 6 L pelarut etanol 96\% selama 5 hari dengan sesekali dilakukan pengadukan. Selanjutnya sari yang diperoleh diuapkan dengan menggunakan rotary evaporator dibawah titik didih hingga diperoleh ekstrak yang kental. 


\section{Pembuatan Larutan Uji}

\section{Pembuatan larutan dapar fosfat}

Pembuatan larutan dapar fosfat $0,01 \mathrm{M} \mathrm{pH} 7,0$ dapat dilakukan dengan cara menimbang 5,99 gram natrium dihidrogen fosfat dan dilarutkan dalam $500 \mathrm{~mL}$ air suling (larutan A). Kemudian sebanyak 8,52 gram natrium hidrogen fosfat ditimbang dan dilarutkan dalam $600 \mathrm{~mL}$ air suling (larutan B). Dari larutan A diambil $255 \mathrm{~mL}$ dan dari larutan B diambil $245 \mathrm{~mL}$, lalu dicampurkan kedua larutan tersebut dan kemudian dicek $\mathrm{pH}$ sampai mencapai 7,0.

\section{Penyiapan sampel}

Penyiapan sampel dilakukan dengan melarutkan sebanyak 10,0 mg ekstrak, masing-masing ekstrak dilarutkan dengan 1 $\mathrm{mL}$ DMSO dan aquadest sampai $10 \mathrm{~mL}$ sehingga diperoleh konsentrasi $1000 \mu \mathrm{g}$. kemudian dibuat seri konsentrasi larutan sampel uji ekstrak.

\section{Pembuatan enzim $\alpha$-amilase}

Pembuatan larutan enzim $\alpha$-amilase dilakukan dengan menimbang sebanyak $(0,5128 \mathrm{U} / \mathrm{mL}) \quad 3,246 \mathrm{mg} \alpha$-amilase dan dilarutkan dalam $100 \mathrm{~mL}$ dapar fosfat $\mathrm{pH}$ 7,0.

\section{Pembuatan larutan amilum}

Pembuatan larutan amilum 0,5\% dilakukan dengan melarutkan $500 \mathrm{mg}$ amylum dalam $100 \mathrm{~mL}$ aquadest kemudian dipanaskan sampai larut.

\section{Pembuatan larutan iodine}

Pembuatan larutan iodin $0,5 \%$ dilakukan dengan melarutkan 0,75 gram kalium iodida dan 0,5 gram iodine dalam $100 \mathrm{~mL}$ aquadest kemudian dipanaskan sampai larut.

\section{Uji Aktivitas Enzim $\alpha$-amilase}

Uji aktivitas $\alpha$-amilase, menurut Mugiyanto (2016) dapat dilakukan dengan tahapan berikut.

\section{Pengujian blanko}

Pengujian blanko dapat diukur dengan mengambil $1000 \mu \mathrm{L}$ dapar fosfat $\mathrm{pH} 7,0$, kemudian diinkubasi selama 10 menit pada suhu $37^{\circ} \mathrm{C}$. Kemudian pada sampel ditambahkan $500 \mu \mathrm{L}$ amilum $0,5 \%$, lalu diinkubasi kembali selama 15 menit pada suhu $37^{\circ} \mathrm{C}$. Setelah masa inkubasi selesai, maka ditambahkan $10 \mu \mathrm{L}$ iodine $0,5 \%$. Absorbansinya diukur dengan spektrofotometer UV-Vis pada panjang gelombang $601 \mathrm{~nm}$.

\section{Pengujian kontrol blanko}

Pengujian kontrol blanko dapat dilakukan dengan pembuatan kontrol blanko. Kontrol blanko dibuat dengan mengambil $1000 \mu \mathrm{L}$ dapar fosfat $\mathrm{Ph}$ 7, kemudian diinkubasi selama 10 menit pada suhu $37^{\circ} \mathrm{C}$. Kemudian pada sampel ditambahkan $500 \mu \mathrm{L}$ amilum $0,5 \%$, lalu inkubasi kembali selama 15 menit pada suhu $37^{\circ} \mathrm{C}$. Setelah masa inkubasi selesai maka ditambahkan $10 \mu \mathrm{L}$ dapar fosfat $\mathrm{pH}$ 7,0. Absorbansinya diukur dengan spektrofotometer UV-Vis pada panjang gelombang $601 \mathrm{~nm}$.

\section{Pengujian sampel}

Pengujian sampel dilakukan dengan pembuatan berbagai konsentrasi. Konsentrasi sampel dibuat dengan mengambil $500 \mu \mathrm{L}$ sampel lalu dibuat berbagai konsentrasi (15, $30,45,60,75 \mathrm{~g} / \mathrm{mL}$ ) dan $500 \mu \mathrm{L}$ enzim $\alpha$ amylase, selanjutnya diinkubasi selama 10 menit pada suhu $37^{\circ} \mathrm{C}$. Selanjutnya ke dalam sampel ditambahkan $500 \mu \mathrm{L}$ amilum 0,5\%, lalu inkubasi kembali selama 15 menit pada suhu $37^{\circ} \mathrm{C}$. Setelah masa inkubasi selesai ditambahkan $10 \mu \mathrm{L}$ iodine $0,5 \%$. Absorbansinya diukur dengan spektrofotometer UV-Vis pada panjang gelombang $601 \mathrm{~nm}$.

\section{Pengujian kontrol sampel}

Pengujian kontrol sampel dilakukan dengan mengambil $500 \mu \mathrm{L}$ sampel dengan berbagai konsentrasi $(15,30,45,60,75$ $\mu \mathrm{g} / \mathrm{ml}$ ) dan $500 \mu \mathrm{L}$ dapar fosfat $\mathrm{pH} 7,0$, kemudian diinkubasi selama 10 menit pada suhu $37^{\circ} \mathrm{C}$. Selanjutnya ke dalam sampel ditambahkan $500 \mu \mathrm{L}$ dapar fosfat $\mathrm{pH} 7,0$. Lalu diinkubasi kembali selama 15 menit pada suhu $37^{\circ} \mathrm{C}$, setelah masa inkubasi selesai, ditambahkan $10 \mu \mathrm{L}$ iodine $0,5 \%$.

Absorbansinya diukur dengan spektrofotometer UV-Vis pada panjang gelombang $601 \mathrm{~nm}$. 


\section{Analisis Data}

Analisis data dilakukan dengan cara menghitung persentase inhibisi $\alpha$-amilase. Data yang diperoleh dari hasil pengukuran absorbansi dapat dihitung \% penghambatan menggunakan persamaan pada rumus 1 .

$$
1-\frac{(\text { abs kontrol - abs sampel })}{\text { abs kontrol }} \times 100 \%
$$

Menurut Sugiwati (2009), perhitungan $\mathrm{IC}_{50}$ menggunakan persamaan regresi linear, konsentrasi sampel sebagai sumbu $\mathrm{x}$ dan \% inhibisi sebagai sumbu y. Nilai IC $_{50}$ dapat dihitung dari persamaan $\mathrm{y}=\mathrm{bx}+\mathrm{a}$, dengan menggunakan rumus 2 .

$$
I C 50=\frac{50-a}{b}
$$

$\mathrm{IC}_{50}$ : nilai aktivitas penghambatan $(\mu \mathrm{g} / \mathrm{mL})$ a : nilai konstanta pada persamaan regresi linier b : nilai gradien pada persamaan regresi linier

\section{HASIL DAN PEMBAHASAN}

Pembuatan simplisia diawali dengan pengumpulan bahan baku berupa tanaman kremah (Alternanthera sessilis). Proses memanen daun kremah dilakukan dengan cara memetik daun dari tanaman yang belum berbunga, karena hal tersebut akan mempengaruhi kadar kandungan senyawa zat aktif dalam simplisia.

Setelah dipetik, daun kremah dilakuan sortasi basah tujuannya untuk memisahkan kotoran atau bahan-bahan asing yang terbawa pada saat pengambilan sampel. Pencucian dengan menggunakan air bersih yang mengalir, tujuannya untuk menghilangkan tanah, mengurangi mikroba dan zat pengotor lain yang melekat pada bahan simplisia. Selanjutnya simplisia dikeringkan dengan panas matahari selama 1 hari dan dilanjutkan dengan oven pada suhu $45^{\circ} \mathrm{C}$, tujuannya untuk mengurangi kadar air sehingga simplisia dapat disimpan dalam waktu yang lama. Setelah simplisia kering, langkah berikutnya yaitu disortasi kering, tujuannya untuk memisahkan pengotor lain yang tertinggal pada simplisia kering. Setelah itu, dihaluskan dan diayak dengan nomor pengayakan 40 mesh sehingga diperoleh serbuk dan disimpan dalam wadah tertutup baik pada suhu $15-30^{\circ} \mathrm{C}$ (Susanti, 2016).

Pada proses ekstraksi metode yang digunakan adalah metode maserasi. Maserasi merupakan metode yang paling mudah dan sederhana. Metode ini dilakukan dengan cara merendam simplisia pada pelarut yang dipilih. Pelarut yang digunakan dalam proses ekstraksi adalah etanol 96\%, karena etanol 96\% merupakan pelarut pengekstrasi yang terpilih untuk pembuatan ekstrak sebagai bahan baku sediaan herbal medicine, dan mudah untuk menembus dinding sel serta masuk ke dalam rongga sel yang mengandung zat aktif sehingga zat aktif akan larut dan karena adanya perbedaan konsentrasi antara larutan zat aktif didalam sel dengan yang diluar sel, maka larutan yang terpekat akan didesak keluar sehingga akan menghasilkan ekstrak kental yang akan lebih mudah dalam proses identifikasi (Pujiyanto, 2019).

Proses maserasi dilakukan dengan cara merendam simplisia dengan pelarut menggunakan perbandingan 1:6, tujuannya untuk meningkatkan tersarinya senyawa kimia yang berada di dalam simplisia. Maserat yang diperoleh dari hasil maserasi ditampung dan dipisahkan dengan pelarutnya menggunakan vacuum rotary evaporator pada suhu $40^{\circ} \mathrm{C}$ dengan kecepatan $60 \mathrm{rpm}$. Prinsip dari vacuum rotary evaporator adalah ekstrak diputar di atas air hangat, sehingga pelarut dari ekstrak akan menguap. Adanya sistem vaccum akan menyebabkan tekanan pada sistem turun mencapai tekanan yang telah diatur sehingga pelarut yang menguap bisa menetes di tempat penampungan. Ekstrak yang telah dipisahkan dari pelarutnya selanjutnya diuapkan di dalam oven untuk menghilangkan sisa pelarut sehingga diperoleh ekstrak yang kental.

Penelitian ini bertujuan untuk mengetahui aktivitas penghambatan ekstrak daun kremah terhadap enzim $\alpha$-amilase. Metode yang digunakan dalam penelitian ini yaitu menggunakan metode secara in-vitro. Larutan 
iodin yang pada dasarnya berwarna kuning kecokelatan akan membentuk senyawa kompleks yang berwarna biru apabila bereaksi dengan pati. Oleh sebab itu, absorbansi yang terukur oleh spektrofotometer UV-Vis pada $\lambda 601 \mathrm{~nm}$ menunjukkan jumlah pati yang tidak terhidrolisis oleh enzim.

Prinsip pengujian sampel yaitu semakin aktif ekstrak yang digunakan, maka semakin sedikit pati yang terhidrolisis sehingga glukosa yang dihasilkan semakin sedikit, karena ekstrak dapat menghambat aktivitas enzim $\alpha$-amilase. Aktivitas enzim $\alpha$-amilase yang dihambat oleh ekstrak tidak dapat bereaksi dengan substrat amilum, sehingga intensitas warna yang dihasilkan akan semakin berkurang (Afriyanti, 2015). Ekstrak yang paling aktif yaitu ekstrak yang menunjukkan \% inhibisi yang paling besar.

Pengujian sampel diawali dengan menghitung \% inhibisi dari masing-masing konsentrasi ekstrak daun kremah dan pembanding yaitu acarbosa. Nilai \% inhibisi menunjukkan kemampuan ekstrak dalam konsentrasi tertentu dapat menghambat aktivitas enzim $\alpha$-amilase. Hasil data pengamatan antara konsentrasi masingmasing ekstrak dan pembanding (Acarbosa) dapat dilihat pada Gambar 1.

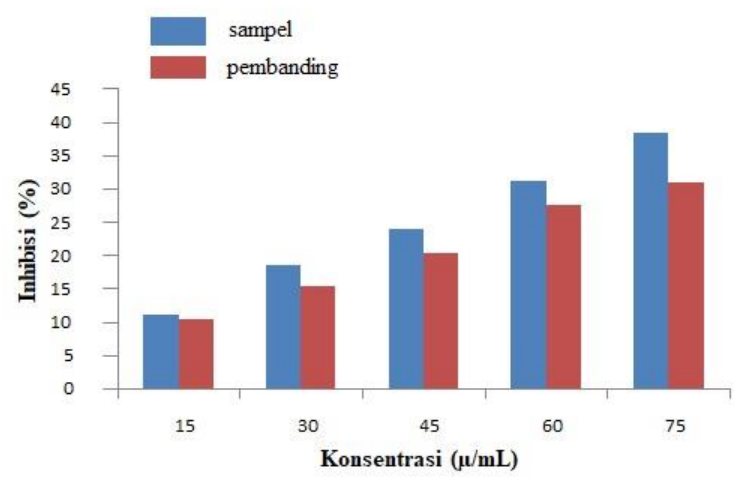

Gambar 1. Hasil uji penghambatan $\alpha$-amilase oleh ekstrak daun kremah dan acarbosa

Ekstrak yang paling aktif yaitu ekstrak yang menunjukkan \% inhibisi yang paling besar. Dilihat dari hasil perbandingan antara sampel ekstrak daun kremah dengan pembanding dapat dikatakan bahwa ekstrak etanol daun kremah mempunyai aktivitas inhibitor $\alpha$-amilase sehingga mampu untuk menghambat kerja enzim $\alpha$-amilase. Aktivitas inhibitor $\alpha$-amilase ekstrak daun kremah lebih baik dari acarbosa, karena dilihat dari nilai persen inhibisi ekstrak etanol pada konsentrasi $75 \mu \mathrm{g} / \mathrm{mL}$ mempunyai nilai persen inhibisi yang lebih besar yaitu $38,30 \%$ daripada acarbosa pada konsentrasi $75 \mu \mathrm{g} / \mathrm{mL}$ yang mempunyai nilai persen inhibisi yaitu 31\%. Menurut Pujiyanto (2017) semakin tinggi konsentrasi sampel yang digunakan maka semakin tinggi aktivitas penghambatan enzim.

Pengujian selanjutnya yaitu menentukan nilai IC 50 . Jumlah konsentasi penghambat yang dapat menghambat enzim $\alpha$-amilase mencapai penghambatan $50 \%$ adalah $\mathrm{IC}_{50}$. Nilai $\mathrm{IC}_{50}$ semakin kecil maka penghambatan yang dihasilkan lebih baik (Afriyanti, 2015). Nilai IC $_{50}$ ditentukan melalui regresi linier, dimana sumbu $\mathrm{x}$ menunjukkan konsentrasi sampel dan sumbu y menunjukkan \% penghambatan. Berdasarkan persamaan $\mathrm{y}=$ $\mathrm{bx}+\mathrm{a}$ dapat dihitung nilai $\mathrm{IC}_{50}$.

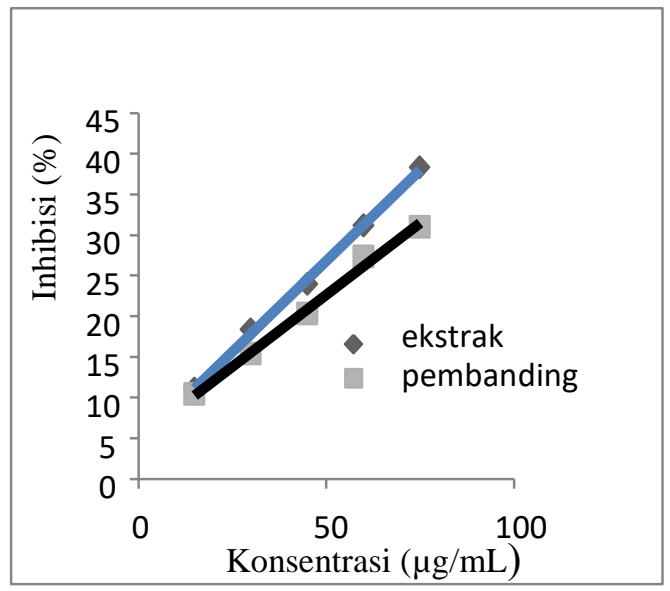

Gambar 2. Regresi linear antara kadar sampel dan $\%$ inhibisi terhadap $\alpha$-amilase

Gambar 2 merupakan hasil kurva baku pengujian antara sampel ekstrak dengan pembanding. Hasil pengujian sampel ekstrak daun kremah dalam menghambat aktivitas $\alpha$ - 
amilase menunjukkan nilai $\mathrm{IC}_{50}$ rata-rata sebesar $101,89 \pm 7,21 \mu \mathrm{g} / \mathrm{mL}$ dengan nilai $\mathrm{r}=$ 0,998 dan persamaan regresi linear $\mathrm{y}=$ $0,447 x+4,4451$. Hasil pengujian standar acarbosa dalam menghambat aktivitas enzim $\alpha$-amilase menunjukkan nilai $\mathrm{IC}_{50}$ rata-rata sebesar $127,17 \pm 4,42 \mu \mathrm{g} / \mathrm{mL}$ dengan nilai $\mathrm{r}=$ 0,992 dan persamaan regresi linear $\mathrm{y}=0,354$ $\mathrm{x}+4,98$. Pengujian standar acarbosa bertujuan untuk mengetahui nilai $\mathrm{IC}_{50}$ dari acarbosa sebagai kontrol positif pengujian dan sebagai pembanding dengan nilai $\mathrm{IC}_{50}$ ekstrak yang diuji.

Tabel 1. Nilai IC $_{50}$ penghambatan $\alpha$-amilase dari ekstrak dan pembanding (acarbosa)

\begin{tabular}{cc}
\hline Sampel & Nilai $^{\text {IC }_{50}(\boldsymbol{\mu g} / \mathbf{m l}) \pm \text { SD }}$ \\
\hline Daun kremah & $101,89 \pm 7,21$ \\
Acarbosa & $127,17 \pm 4,22$ \\
\hline
\end{tabular}

Berdasarkan Tabel 1, hasil pengujian nilai $\mathrm{IC}_{50}$ ekstrak daun kremah dan pembanding (acarbose) menunjukkan nilai $\mathrm{IC}_{50}$ ekstrak daun kremah lebih kecil daripada acarbosa, yang menunjukkan ekstrak daun kremah memiliki kemampuan penghambatan aktivitas enzim $\alpha$-amilase yang lebih baik. Hal ini dikarenakan daun kremah mempunyai senyawa kimia aktif yang dapat menghambat aktivitas enzim $\alpha$-amilase. Senyawa-senyawa tersebut dapat dilihat dari hasil skrining fitokimia, namun senyawa yang berpotensi dalam menghambat enzim $\alpha$-amilase adalah senyawa golongan glikosida, alkaloid dan flavonoid (Pujiyanto, 2019). Selain itu, senyawa xanton yang merupakan golongan flavanoid telah terbukti secara in-vitro menghambat aktivitas enzim $\alpha$-amilase. Senyawa flavanoid lainnya juga telah terbukti mampu untuk menghambat aktivitas $\alpha$ glukosidase dan $\alpha$-amilase (Tadera et al., 2005).

\section{KESIMPULAN}

Berdasarkan hasil penelitian yang diperoleh maka dapat disimpulkan bahwa ekstrak daun kremah dapat menghambat aktivitas enzim $\alpha$ amilase dengan nilai $\mathrm{IC}_{50}$ lebih kecil dibandingkan dengan acarbose . Nilai $\mathrm{IC}_{50}$ ekstrak daun kremah yaitu $101,89 \pm 7,21 \mu \mathrm{g} / \mathrm{mL}$ dan nilai $\mathrm{IC}_{50}$ acarbose yaitu $127,17 \pm 4,42 \mu \mathrm{g} / \mathrm{mL}$.

\section{Daftar Pustaka}

Afriyanti, T. 2015, Uji potensi antidiabetik pada ekstrak daun Garcinia mangostana L. melalui penghambatan aktifitas alfa glukosidase dan alfa amilase serta penapisan fitokimia pada ekstrak teraktif. Universitas Indonesia

Goel, R., Dask, B., Sadaf, J.G., and Deepti, K. 2012. Medicinal plants as anti-diabetics: a review. International Bulletin of Drug Research; 1 (2) :100-107

Mrinmay, D., Ashok, K.D., Mastanaiah, K., and Das, A. 2015. Evaluation of anti-diabetic activity of ethanolic extract of Alternanthera sessilis Linn. in streptozotocin-induced diabetic rats. International Journal of Pharma Sciences and Research (IJPSR); 6 (7) : 1027-1032

Pujiyanto, S., Wijanarka., Budi, R and Via, A. 2019. Aktivitas inhibitor $\alpha$-amilase ekstrak etanol tanaman brotowali (Tinospora crispa L.). Bioma; 21 (2) : 91-99

Rizza, R.A. 2010. Pathogenesis of fasting and postprandial hyperglycemia in type 2 diabetes: Implications for Therapy. Diabetes Journal; 59(1): 2697-2707 
Sugiwati S., Siswati S., and Efy, A. 2019. Antihyperlycemic activity of the mahkota dewa (Phaleria macrocarpa (Scheff.) Boerl.) leaf extracts as an alphaglucosidase inhibitor. Makara Kesehatan; 13 (2): 74-78

Tadera, K., Yuji, M., Kouta, T., and Tomoko, M. 2005. Inhibition of $\alpha$-glukosidase and $\alpha$ amylase by flavonoids. Japan : Kagoshima University

Verma, S., Madhu, .G, Harvinder, P., \& Geeta, A. 2018. Diabetes mellitus treatment using herbal drugs. International Journal Of Phytomedicine; 10(1) : 1-10 